19. Пчелін В.Б. Перегляд адміністративних актів органів внутрішніх справ : дис. ... канд. юрид. наук : спец. 12.00.07. Харків, 2011. 190 с.

20. МВФ офіційно оприлюднив меморандум по новій програмі для України // УНІАН. URL : https://www.unian.ua/economics/finance/10401945-mvf-oficiyno-oprilyudniv-memorandumpo-noviy-programi-dlya-ukrajini.html.

21. Про перелік, кількісний склад і предмети відання комітетів Верховної Ради України восьмого скликання: постанова Верховної Ради України від 04.12.2014 № 22-VIII. Вiдомості Верховної Ради Украӥни. 2015. № 1. Ст. 10.

СТЕЦЮК С.П.

\title{
УДОСКОНАЛЕННЯ ФУНКЦІЇ ПЛАНУВАННЯ МІНІСТЕРСТВА ОБОРОНИ УКРАЇНИ В УМОВАХ ПІВНІЧНОАТЛАНТИЧНОЇ ІНТЕГРАЦЇ̈
}

Стаття присвячена проблемам удосконалення функції планування Міністерства оборони України в умовах північноатлантичної інтеграції. Автор визначає основні чинники підвищення важливості функції планування у секторі безпеки і оборони. Такі чинники включають збройну агресію Російської Федерації, внаслідок якої Збройні Сили України функціонують в умовах особливого режиму; конституційне закріплення стратегічного курсу держави на набуття повноправного членства України в Організації Північноатлантичного договору; значні обсяги державних коштів на формування оборонного бюджету.

У статті досліджено наукові підходи щодо розуміння категорії «планування». Визначено коло суб'єктів, які відіграють ключову роль у здійсненні оборонного планування. Визначено особливості документів довгострокового, середньострокового та короткострокового планування. Автор доводить, що основною та об'єднуючою метою документів планування є: 1) реформування складників сектору безпеки і оборони за рахунок збільшення їх спроможностей до рівня євроатлантичних стандартів, покликаних забезпечити виконання завдань оборони держави і відновлення ії територіальної цілісності; 2) активна участь у реалізації спільної безпекової і оборонної політики Європейського Союзу та розширення співробітництва із НАТО з досягненням критеріїв, необхідних для набуття повноправного членства в цій організації.

У статті обгрунтовано, що планування як функція Міністерства оборони України $є$ процесом визначення дій і розподілу ресурсів, необхідних для досягнення поставлених цілей. Активізація північноатлантичної інтеграції зумовлює перебудову процесу планування Міністерства оборони України шляхом зміни його методології: від планування на основі загроз оборонне відомство поступово переходить до планування на основі спроможностей. Натепер необхідним $є$ продовження роботи над виробленням єдиних методичних вимог до документів планування з урахуванням Єдиного переліку (каталогу) спроможностей Міністерства оборони України та Збройних Сил України, що має визначити напрями подальших наукових розвідок.

Ключові слова: планування, функиії управління, Міністерство оборони України, орган виконавчої влади, північноатлантична інтеграчія.

(C) СТЕЦЮК С.П. - ад’юнкт науково-організаційного відділення (Військовий інститут Київського національного університету імені Тараса Шевченка) 
The article is devoted to the problems of improving the planning function of the Ministry of Defense of Ukraine in the context of North Atlantic integration. The author identifies the main factors of increasing the importance of the planning function in the security and defense sector. Such factors include: firstly, the armed aggression of the Russian Federation, as a result of which the Armed Forces of Ukraine operate in a special regime; secondly, the constitutional consolidation of the state's strategic course towards the acquisition of full membership of Ukraine in the North Atlantic Treaty Organization; thirdly, significant amounts of state funds for the formation of the defense budget.

The article explores the scientific approaches to understanding the category of "planning". The circle is defined by actors who play a key role in the implementation of military planning. Features identified documents long-term, medium-term and shortterm planning. The author proves that the main and unifying purpose of the planning documents is: 1) the reform of the components of the security and defense sectors by increasing their capabilities to the level of Euro-Atlantic standards, is designed to ensure the fulfillment of the state's defense tasks and the restoration of its territorial integrity; 2) active participation in the implementation of the Joint Security and Defense Policy of the European Union and the expansion of cooperation with NATO with the achievement of the criteria necessary for gaining full membership in this organization.

The article substantiates that planning as a function of the Ministry of Defense of Ukraine is a process of determining the actions and allocation of resources necessary to achieve the goals. The intensification of North Atlantic integration leads to a restructuring of the planning process of the Ministry of Defense of Ukraine by changing its methodology: from defense-based planning, the defense department is gradually shifting to capacity-based planning. Attention is focused on the fact that today it is necessary to continue working on the development of uniform methodological requirements for planning documents, taking into account the Unified List (catalog) of capabilities of the Ministry of Defense of Ukraine and the Armed Forces of Ukraine, which should determine the directions for further scientific research.

Key words: planning, management functions, Ministry of Defense of Ukraine, executive authority, North Atlantic integration.

Вступ. Удосконалення системи виконавчої влади в Україні передбачає перегляд традиційних підходів до сутності та змісту функції планування, без застосування якої будь-які кардинальні звершення залишаться нереалізованими. Особливо гостро питання удосконалення функції планування постає у секторі безпеки і оборони, що зумовлено трьома факторами: збройною агресією Російської Федерації, внаслідок якої Збройні Сили України вже сьомий рік поспіль функціонують в умовах особливого режиму; конституційне закріплення стратегічного курсу держави на набуття повноправного членства України в Організації Північноатлантичного договору, що вносить свої корективи у систему планування; значними обсягами державних коштів на формування оборонного бюджету, що робить особливо відповідальним процес їх раціонального використання та потребує науково обгрунтованого планування таких витрат. Однак, незважаючи на важливість визначення сутності та особливостей реалізації функції планування у діяльності Міністерства оборони України, на жаль, у теоретичних джерелах вона ще досліджена не досить. Вказане зумовлює важливість та актуальність обраної теми статті.

Проблематику правового забезпечення функціонування Міністерства оборони України та Збройних Сил України розглядали у своїх роботах В.О. Заросило, В.Л. Зьолка, І.М. Коропатнік, Т.О. Кузьменко, В.Я. Настюк, В.Й. Пашинський, С.В. Пєтков, В.Г. Пилипчук, А.П. Поляков, В.В. Сокуренко, О.О. Сурков, В.А. Тимошенко, В.В. Топольніцький, В.С. Цимбалюк, І.М. Шопіна, В.В. Шульгін, О.Н. Ярмиш та інші вчені. Разом із тим питання планування як управлінська функція органу виконавчої влади, який забезпечує формування та реалізує державну політику з питань національної безпеки у воєнній сфері, сферах оборони і військового будівництва у мирний час та особливий період, залишається не досить дослідженою.

Постановка завдання. Метою статті є визначення сутності функції планування Міністерства оборони України в умовах північноатлантичної інтеграції.

Результати дослідження. Перш ніж розпочати дослідження, автор звертається до джерел, в яких тлумачиться сутність терміну «планування». В Енциклопедії державного управління планування як функція державного управління розуміється як визначення перспектив і майбутнього 
стану організації, шляхів і способів його досягнення за певний період часу $[1$, с. 668]. Метою функції планування є створення системи поточних і стратегічних завдань та цілей, які визначають зміст і певний порядок дій суб'єктів державного управління [2, с. 524]. Формуючи систему цілей і завдань планування, обов'язково слід мати на увазі, що вони повинні бути конкретними i підлягати вимірюванню; охоплювати всі ієрархічні рівні організації; мати різну тривалість; бути досяжними і зрозумілими; взаємодоповнювальними та взаємоузгодженими [3, с. 76].

Процес планування грунтується на складанні планувальних документів, зміст і перелік яких $є$ нормативно врегульованим, та здійснюється у встановленому порядку спеціальними суб' єктами державного управління. Документи з планування можна класифікувати за терміном дії (поточні, коротко-, середньо- та довгострокові - вони відрізняються за терміном, ступенем достовірності, рівнем деталізації і обгрунтованістю); за об'єктом планування (організаційні, структурних підрозділів, виконавців); за напрямом забезпечення досягнення мети організації (оборонні, безпекові, кадрові, технічні, фінансові, інноваційні, матеріального забезпечення); за постановкою (цільове планування, планування від досягнутого) [1, с. 668].

Одним із прикладів реалізації функції планування у діяльності Міністерства оборони України може слугувати виконання покладених на нього завдань із організації в силах оборони заходів оборонного планування. Натепер момент ключову роль у здійсненні оборонного планування відіграють Департамент воєнної політики, стратегічного планування та міжнародного співробітництва Міністерства оборони України та Головне управління оборонного та мобілізаційного планування Генерального штабу Збройних Сил України.

Закон України «Про національну безпеку України» визначає термін «оборонне планування» як складову частину системи державного стратегічного планування, що здійснюється 3 метою забезпечення обороноздатності держави шляхом визначення пріоритетів і напрямів розвитку сил оборони, їх спроможностей, озброєння та військової техніки, інфраструктури, підготовки військ (сил), а також розроблення відповідних концепцій, програм і планів з урахуванням реальних і потенційних загроз у воєнній сфері та фінансово-економічних можливостей держави [4].

Оскільки співвідношення згаданих вище термінів $є$ тотожним до співвідношення філософських категорій «частина» та «ціле», то логічно також з'ясувати сутність державного стратегічного планування. Автор зауважує, що, незважаючи на численні згадки цього терміну в різних нормативно-правових актах, чинне законодавство України не розкриває його зміст. У наукових колах державне стратегічне планування пропонується розглядати як систематичний процес формування державної політики, який на основі визначення мети та основних цілей розвитку країни з урахуванням наявних ресурсів дозволяє визначити пріоритети державної політики, що мають бути спрямовані на реалізацію національних інтересів і досягнення на цій основі прогресивного соціально-економічного розвитку. Специфічною особливістю державного стратегічного планування $\epsilon$ те, що воно характеризується великим масштабом і різноманітністю стратегічних документів, які охоплюють всі сфери життєдіяльності суспільства [5, с. 119].

Планування у сферах безпеки і оборони реалізується шляхом розроблення стратегій, концепцій, програм, планів розвитку органів сектору безпеки і оборони, управління ресурсами та ефективного їх розподілу. Воно поділяється на довгострокове (понад п'ять років), середньострокове (до п'яти років) та короткострокове (до трьох років).

Документами довгострокового планування є Стратегія національної безпеки України, Стратегія воєнної безпеки України, Стратегія громадської безпеки та цивільного захисту України, Стратегія розвитку оборонно-промислового комплексу України, Стратегія кібербезпеки України та Національна розвідувальна програма.

Документами середньострокового планування $є$ інші стратегічні документи, програми щодо розвитку складників сектору безпеки і оборони, зокрема оснащення їх сучасним озброєнням і військовою технікою, створення необхідних запасів матеріально-технічних засобів і необхідних для цього потужностей оборонно-промислового комплексу, реалізація інших заходів із посилення обороноздатності держави. До цієї категорії документів належить Концепція розвитку сектору безпеки і оборони України, Стратегічний оборонний бюлетень України, Державна програму розвитку Збройних Сил України та інше.

Короткострокове планування передбачає щорічне розроблення планів утримання та розвитку (діяльності) складників сектору безпеки і оборони, основних показників державного оборонного замовлення, в яких визначаються завдання щодо реалізації документів довгострокового і середньострокового планування. До цієї категорії можна віднести Програми розвитку видів, окремих родів військ, Збройних Сил, державні цільові оборонні програми розвитку за окремими 
напрямами, щорічні плани утримання та розвитку Збройних Сил, видів, окремих родів військ, сил, плани організаційних заходів, підготовки Збройних Сил та інше.

Найважливіше місце серед документів планування у сфері національної безпеки і оборони займає Стратегія національної безпеки України, яка $є$ основою для підготовки всіх інших документів із планування. Необхідною передумовою для розробки документів планування у сфері національної безпеки і оборони є проведення комплексного огляду сектору безпеки і оборони, що $є$ процедурою оцінювання стану і готовності складників сектору безпеки і оборони до виконання завдань за призначенням.

Комплексний огляд сектору безпеки і оборони включає проведення оборонного огляду, огляду громадської безпеки та цивільного захисту, огляду оборонно-промислового комплексу, огляду розвідувальних органів України, огляду загальнодержавної системи боротьби з тероризмом, огляду стану кіберзахисту державних інформаційних ресурсів і критичної інформаційної інфраструктури [4]. Система документів планування у сфері національної безпеки і оборони та процес їх розроблення нині $є$ відносно регламентованими.

Що стосується змісту документів планування у сфері національної безпеки і оборони, то їх основною та об'єднуючою метою є: 1) реформування складників сектору безпеки і оборони за рахунок збільшення їх спроможностей до рівня євроатлантичних стандартів, покликане забезпечити виконання завдань оборони держави і відновлення iіi територіальної цілісності; 2) активна участь у реалізації спільної безпекової і оборонної політики Європейського Союзу та розширення співробітництва із НАТО з досягненням критеріїв, необхідних для набуття повноправного членства в цій організації.

Поряд із позитивними аспектами залишається і низка невирішених проблем. Зокрема, в якості недоліків варто зазначити відсутність єдиного підходу та системності в процесі опрацювання документів планування, що призводить до хаотичності їх змісту, викликає неузгодженість між різними стратегічними та плановими документами. Досить часто одні й ті самі цілі мігрують із документа в документ та із року в рік із тією різницею, що у різних документах вони посідають різні ієрархічні позиції в переліку пріоритетів або завдань і відрізняються за редакційним викладенням (наприклад мета може бути пріоритетом, напрямом або завданням у наступних документах) [6].

Деякі положення документів планування не містять чітких заходів і завдань, оцінки можливих результатів їх реалізації, що унеможливлює існування ефективної системи оцінювання виконання планів. До того ж натепер відсутні будь-які чітко регламентовані політичні чи юридичні наслідки за невиконання вимог планів чи прийняття неефективних управлінських рішень під час їх виконання. І останньою та напевно найбільш гострою проблемою в реалізації планів $\epsilon$ дисбаланс між плановими документами і бюджетом.

У зв'язку із викладеними проблемами та прагненнями України вступити до НАТО вітчизняне оборонне планування потребує реформування. Базою такого реформування має стати всеосяжне запровадження методології планування на основі спроможностей (Capabilities Based Planning), яка пройшла апробацію в багатьох державах-членах HATO і визнана експертами найперспективнішою в оборонному плануванні. Вона спрямована на виявлення та надання рекомендацій щодо найбільш прийнятних за критерієм «вартість - ефективність» варіантів розвитку військ (сил). На відміну від планування на основі загроз, оборонне планування на основі спроможностей полягає в зосередженні зусиль не на збільшенні ресурсів для забезпечення переваги відповідному бойовому потенціалу противника, а на створенні, розвитку і підтримці оптимального складу необхідних спроможностей у межах наявних ресурсів [7, с. 50-56].

Спроможність (оперативна, бойова, спеціальна) - це здатність структурної одиниці (елементу) збройних сил (сил оборони) або сукупності сил і засобів виконувати певні завдання (забезпечувати реалізацію визначених військових цілей) за певних умов обстановки, ресурсного забезпечення та відповідно до встановлених стандартів [8]. Тож на практиці оборонне планування на основі спроможностей передбачає здійснення функціонального аналізу, у ході якого функції та завдання, які мають виконуватися під час очікуваних (вірогідних) майбутніх операцій, трансформуються у вимоги до спроможностей, на підставі чого планується їх створення, утримання та розвиток [9].

Відповідно до євроатлантичних стандартів в Україні створено Єдиний перелік (каталог) спроможностей Міністерства оборони України та Збройних Сил України [10], який містить 464 спроможності. Всі ці спроможності прийнято об'єднувати у певні функціональні групи: забезпечення готовності військ (FORCE SUPPORT) - охоплює інституційні спроможності 
3 оборонного менеджменту (керівництво силами оборони), підготовки військ (сил оборони) до оборони, генерування сил, менеджменту персоналу та забезпечення соціального захисту військовослужбовців і членів їх сімей; співробітництво у сфері безпеки і оборони (PREPARE) - охоплює спроможності із забезпечення регіональної безпеки, зокрема шляхом надання (отримання) допомоги з нарощення (розвитку) оперативних спроможностей країн-партнерів, а також спроможностей національних сил і засобів; розгортання та мобільність військ (PROJЕСТ) - охоплює спроможності засобів доставки, підготовки військ (сил) до висування / перекидання у райони призначення та організації базування з урахуванням визначених термінів готовності; застосування (ENGAGE) - охоплює спроможності частин та підрозділів видів і родів військ (сил оборони) з виконання основних завдань за призначенням як самостійно, так і у складі міжвидових угруповань; забезпечення (SUSTAIN) - охоплює спроможності у сфері бойового, тилового, технічного та медичного забезпечення; керівництво та управління (CONSULT, COMMAND \& CONTROL) - охоплює спроможності органів управління стратегічного, оперативного та тактичного рівнів з управління застосуванням військ (сил); захист і живучість (РROTECT) - охоплює спроможності щодо забезпечення захисту від загроз із повітря, моря, протимінної боротьби, РХБ захисту, контррозвідки, мобільної та статичної кібернетичної оборони, придушення засобів РЕР / РЕБ противника; розвідка (INFORM) - охоплює спроможності з ведення розвідки, спостереження та цілевказання (на стратегічному, оперативному та тактичному рівнях); військово-політичне керівництво, управління ресурсами (CORPORATE MANAGEMENT \& SUPPORT) - охоплює інституційні спроможності щодо нормативно-правового забезпечення, здійснення аудиту, інспектування та всеохоплюючого оцінювання (оглядів), розроблення стратегій, планування розвитку спроможностей, організації закупівель, програмного менеджменту та ресурсного забезпечення, бюджетного планування та обліку [11].

Через відмінності в структурах збройних сил, процесах планування та вимогах законодавства кожна країна-член НАТО реалізує власний метод планування на основі спроможностей, проте найпоширенішим із них $є$ той, що включає п'ять основних етапів, які мають послідовний і циклічний характер [12]: визначення засад державної політики у сфері безпеки і оборони; визначення необхідних спроможностей військ (сил) для виконання завдань; розподіл спроможностей і визначення завдань; імплементація; оцінка результатів. Таким чином стає абсолютно очевидним, що першим і водночас найскладнішим кроком України у створенні перспективної системи оборонного планування має бути розроблення її власного методичного забезпечення, основою якого мають бути кращі напрацювання країн-членів НАТО.

Висновки. На підставі викладеного вище можна зробити певні висновки. Так, планування як функція Міністерства оборони України є процесом визначення дій і розподілу ресурсів, необхідних для досягнення поставлених цілей. Активізація північноатлантичної інтеграції зумовлює перебудову процесу планування Міністерства оборони України шляхом зміни його методології: від планування на основі загроз оборонне відомство поступово переходить до планування на основі спроможностей. Разом із тим необхідним є продовження роботи над виробленням єдиних методичних вимог до документів планування з урахуванням Єдиного переліку (каталогу) спроможностей Міністерства оборони України та Збройних Сил України, що має визначити напрями подальших наукових розвідок.

\section{Список використаних джерел:}

1. Енциклопедія державного управління: у 8 т. / Нац. акад. держ. упр. при Президентові України. Т. 2: Методологія державного управління / наук.-ред. колегія: Ю.П. Сурмін, П.І. Надолішній та ін. Київ : НАДУ, 2011. 692 с.

2. Кравцова Т.М., Калініченко Г.В. Дослідження функцій державного управління та їх значення у процесі державно-управлінської діяльності. Форум права. 2011. C. 522-527. URL: http://www/nbuv.gov.ua./e-journals/FP/2011-1/11ktmdud.pdf (дата звернення: 11.12.2019).

3. Шморгун Л.Г. Менеджмент організацій : навчальний посібник. Київ : Знання, 2010. 452 с.

4. Про національну безпеку України : Закон України від 21.06.2018 № 2469-VIII. URL: https://zakon.rada.gov.ua/go/2469-19 (дата звернення: 05.12.2019).

5. Свмєшкіна О.Л. Теоретико-методологічні засади модернізації системи державного стратегічного планування в Україні : монографія. Київ : Нац. акад. держ. упр. при Президентові України; УкрСІЧ, 2017. 394 с.

6. Рекомендації щодо стратегічного планування економічного і соціального розвитку України на довгострокову перспективу [Підготовлено в рамках Проєкту «Прискорення про- 
гресу в досягненні Цілей розвитку тисячоліття в Україні» (Acceleration of MDGs progress in Ukraine) Програми Розвитку ООН в Україні. Київ, 2012. 17 с. URL: http://www.undp.org.ua/files/ ua_59817AMDGP_strategic_planning_ukr.pdf.

7. Бойко Р.․‥ Формування підходів до планування спроможностей військ (сил) з урахуванням їх ресурсного забезпечення / Р.В. Бойко, М.П. Бутенко, В.М. Гудим. Збірник наукових прачь Центру воєнно-стратегічних досліджень Національного університету оборони України імені Івана Черняховського. 2017. № 3. С. 50-56.

8. Про затвердження Порядку проведення оборонного огляду Міністерством оборони : Постанова Кабінету Міністрів України від 31.10.2018 № 941. URL: https://zakon.rada.gov.ua/ go/941-2018-\%D0\%BF (дата звернення: 05.12.2019).

9. Рекомендації з оборонного планування на основі спроможностей Міністерства оборони України та Збройних Сил України URL: http://www.mil.gov.ua/content/other/Recommendationson_ CBP_120617.pdf (дата звернення: 05.12.2019).

10. Єдиний перелік (каталог) спроможностей Міністерства оборони України та Збройних Сил України. Затверджено Міністром оборони України від 28.11.2017 р. Київ : МОУ, 2017. 356 с.

11. Capability Based Planning for the Department of National Defence and the Canadian Forces. Department of National Defence, 2002. P. 24-27.

12. Дєнєжкін М.М., Наливайко А.Д., Поляєв А.І. Особливості оборонного планування у державах-членах НАТО на основі спроможностей. Зб. наук. пр. ЦНДІ ЗСУ. 2017. № 3 (77). C. 34-38.

УДК 342.9.083.4:[351.74:004](477)

DOI https://doi.org/10.32844/2618-1258.2019.6.42

ТКАЧ Т.В.

\title{
ЮРИДИЧНІ ГАРАНТІЇ ДІЯЛЬНОСТІ ДЕПАРТАМЕНТУ КІБЕРПОЛЦЦЇ НАЦІОНАЛЬНОЇ ПОЛЦІЇ УКРАЇНИ
}

\begin{abstract}
У статті розглядаються актуальні питання правових гарантій діяльності міжрегіонального органу державної влади - Департаменту кіберполіції Національної поліції України. Встановлено, що правові гарантії діяльності Департаменту кіберполіції Національної поліції України є одним із важливих складників ії̈ адміністративно-правового статусу, що визначає його сутність. Визначено, що юридичні гарантії діяльності кіберполіції Національної поліції України включають: 1) юридичні гарантії професійної діяльності управління кіберполіції; 2) правові гарантії діяльності Департаменту кіберполіції; 3) матеріально-технічні гарантії діяльності відділу кіберполіції; 4) соціально-економічні гарантії діяльності Департаменту кіберполіції. Виявлено, що правові гарантії діяльності управління кіберполіції займають особливе місце в механізмі його адміністративно-правового статусу, оскільки вони покликані забезпечити режим найбільшої допомоги у здійсненні відповідного суб'єктивного характеру прав і виступають як реальний важіль, що дозволяє забезпечити реалізацію встановленої законом правової поведінки. У статті автор наголошує, що не менш важливою юридичною гарантією є право працівників Департаменту кіберполіції на використання вогнепальної зброї, спеціальних засобів та фізичного впливу. Зокрема, чинний Кримінальний кодекс України містить низку статей, які криміналізують протиправні дії щодо працівника поліції. Автор під поняттям «юридичні гарантії діяльності» розуміє правові гарантії професійної діяльності Департаменту кіберполіції Національної поліції України, а також їх охорону, захист та відновлення у разі порушення. Зроблено висновок,
\end{abstract}

(C) ТКАЧ Т.В. - аспірант кафедри поліцейського права (Національна академія внутрішніх справ) 